\title{
STUDI KOMPARASI OPERASIONAL PRODUK PEGADAIAN SYARIAH DAN GADAI KONVENSIONAL
}

\author{
${ }^{1}$ Muh. Ishak Agus, ${ }^{2}$ Syahruddin Yasen \\ ${ }^{1}$ Prodi Hukum Ekonomi Syariah FAI Unismuh Makassar | ishak.agus18@ gmail.com \\ ${ }^{2}$ Universitas Muslim Indonesia Makassar
}

\begin{abstract}
Abstrak
Menurut kitab Undang-undang Hukum Perdata Pasal 1150, gadai adalah hak yang diperoleh seseorang yang mempunyai piutang atas suatu barang bergerak. Barang bergerak tersebut diserahkan kepada orang yang berpiutang oleh seorang yang mempunyai utang atau oleh seorang lain atas nama orang yang mempunyai utang. Dan masyarakat masih menganggap perusahaan syariah dan konvensional sama. Padahal jika dilihat dari segi operasional dan landasan hukumnya jelas berbeda yang dimana pegadaian syariah berpedoman pada Al-Qur'an surah Al-Baqarah ayat 278 tentang larangan riba. Hal ini menunjukkan bahwa produk Ar-Rahn menjadi pilihan terbaik untuk nasabah dalam mengambil keputusan memilih produk gadai syariah atau ar-Rahn.
\end{abstract}

Kata kunci : Nasabah, Produk Pegadaian syariah, Gadai Konvensional 


\begin{abstract}
According to the Book of the Civil Code Article 1150, pledge is the right earned by a person who has receivables on a moving good. The moving goods are handed over to the person who is indebted by a person who has a debt or by another person on behalf of the person having the debt. And society still considers sharia and conventional companies alike. Whereas when viewed from the operational point of view and the legal basis is clearly different where the shariah pawn is guided by Al-Qur'an surah Al-Baqarah verse 278 about the prohibition of usury. This shows that the product of ArRahn becomes the best choice for the customer in making decision to choose the product of pawn of shariah or ar-Rahn.
\end{abstract}

Keywords: Customer, Sharia Pawn Products, Conventional Pawn

\section{PENDAHULUAN}

N $\begin{aligned} & \text { enurut kitab Undang- } \\ & \text { undang Hukum Perdata }\end{aligned}$

Pasal 1150, gadai adalah hak yang diperoleh seseorang yang mempunyai piutang atas suatu barang bergerak. Barang bergerak tersebut diserahkan kepada orang yang berpiutang oleh seorang yang mempunyai utang atau oleh seorang lain atas nama orang yang mempunyai utang. Seorang yang berutang tersebut memberikan kekuasaan kepada orang berpiutang untuk menggunakan barang bergerak yang telah diserahkan untung melunasi utang apabila pihak yang berutang tidak dapat memenuhi kewajibannya pada saat jatuh tempo.

Secara umum, perusahaan pehadaian adalah suatu badan usaha di Indonesia yang secara resmi mempunyai izin untuk melaksanakan kegiatan lembaga keuangan berupa pembiayaan dalam bentuk penyaluran dana masyarakat atas dasar hukum gadai.

Dari uraian diatas, dapat disimpulkan bahwa gadai adalah suatu hak yang diperoleh oleh orang yang orang yang berpiutang atas suatu barang yang bergerak. sedangkan yang diserahkan oleh orang yang berpiutang sebagai jaminan utangnya dan barang tersebut dapat dijual oleh yang berpiutang bila yang berutang tidak dapat melunasi kewajibannya pada saat jatuh tempo.

Pada masa pemerintahan RI, dinas pegadaian yang merupakan kelanjutan dari Pemerintah HindiaBelanda, status pegadaian diubah menjadi Perusahaan Negara (PN) Pegadian berdasarkan UU No. 19 PRp 1960 jo. Peraturan Pemerintah RI No. 
178 tahun 1960 tanggal 3 mei 1961 tentang pendirian perusahaan pegadaian (PN Pegadaian). Kemudian berdasarkan peraturan pemerintah RI No. 7 tahun 1969 tanggal 1 agustus 1969 tentang perubahan kedudukan PN pegadaian menjadi jawatan pegadaian jo. UU No. 9 tahun 1969 tanggal 1 agustus dan penjelasannya mengenai bentuk-bentuk usaha Negara dalam Perusahaan Jawatan (Perjan), Perusahaaan Umum (Perum), dan persahaan Perseroan (Persero). Selanjutnya untuk meningkatkan efektifitas dan produktifitasnya, bentu Perjan Pegadaian tersebut kemudian dialihkan menjadi Perusahaan Umum (Perum) Pegadaian berdasarkan Peraturan Pemerintah No. 10 Tahun 1990 tanggal 10 April 1990. Dengan perubahan status dari Perjan menjadi Perum, pegadaian diharapkan akan lebih mempu mengelola usahanya dengan lebih professional, bussines oriented tanpa meninggalkan ciri khusus misinya, yaitu penyaluran uang pinjaman atas dasar Hukum Gadai dengan pasar sasaran adalah masyarakat golongan ekonomi lemah dan denga cara mudah, cepat, aman, dan hemat sesua dengan mottonya
"Menyelesaikan Masalah tanpa Masalah".

Belakangan, bersamaan dengan berkembangnya produk-produk berbasis syariah yang kian marak di Indonesia, sector pegadaian juga ikut mengalaminya. Pegadaian syariah hadir dalam bentuk mitra kerja antara bank syariah dengan Perum Pegadaian membentuk Unit Layanan Gadai Syariah dibeberapa kota di Indonesia. Disamping itu adapula bank syariah yang menjalankan produk gadai (arRahn) sendiri.

Pegadaian syariah dalam menjalankan operasionalnya berpegang pada prinsip syariah. Pada dasarnya, produk-produk prinsip syariah memiliki karakteristik seperti, tidak memugut bunga dalam berbagai bentuk karena riba, menetapkan uang sebagai alat tukar dan bukan sebagai komoditas yang diperdagangkan, dam melakukan bisnis untuk mendapatkan balas jasa/bagi hasil.

Perusahaan gadai secara teknis berada dibawah Departemen Ditjen Keuangan. Secara operasioanl pengawasan kerja dilakukan oleh Ditjen Moneter meliputi proses penilaian \& pengesahan rencana kerja 
dan anggaran perusahaan, pemberian izininvestasi, penarikan kredit, \&pelepasan kekayaan milik perusahaan, penilaian laporan keuangan, dan kinerja manajemen dan kinerja perusahaan.

Produk ar-Rahn ini berjalan sesuai dengan syariat Islam yang dimana diharamkan sepesepun pihak penerima gadai menerima bunga dalam berbagai macam bentuk disetiap pelunasan kredit yang dimana barang jaminan milik nasabah dipegang oleh pihak penerima gadai selama kredit yang disaurkan ke nasabah itu telah lunas dan berakhirnya suatu gadai. Gadai (ar-Rahn) ini sendiri lebih transparan karena apabila barang milik nasabah digadai karena tidak mampu melunasi kreditnya, barang jaminan itulah yang akan digadai oleh pihak penggadai (perbankan/ perusahaan gadai) dan setelah ditaksir, nilainya akan dibandingkan dengan jumlah kredit nasabah tersebut.

Berbeda dengan gadai konvensional yang lebih dikenal baik oleh masyarakat yang dimana gadai ini (ar-Rahn) hanya mengenal jasa simpan atas arang yang dijadikan jaminan oleh nasabah dan jasa simpan tesebut dibayar setiap bulannya bersama dengan angsuran kreditnya. Jasa simpan tersebut tidak menggunakan persentase seperti bunga. Hanya menentukan nilai nominal rupiah dan ditetukan oleh pihak penggadai. Biasanya hanya memasang tarif jasa sebesar Rp.4.000 rupiah setiap bulannya.

Dalam ekonomi syariah terkhusus dalam transaksi gadai jelasjelas Allah swt. Melarang hambanyaNya melakukan transaksi yang mengandung unsur riba. Karena riba adalah sebuah transaksi yang diberikan oleh seseorang dan mengharapkan imbalan atas suatu kebaikan yang diberikan kepada seseorang tanpa memikirkan dampak-nya seperti memberikan bantuan pinjaman materi berupa uang. Dalam praktik ini uang bukanlah sebagai komoditas yang diperjualbelikan. Melainkan uang hanyalah sebatas alat tukar menukar. Jadi apabila seseorang meminjamkan uang kepada seseorang, haram hukumnya bila jumlah pinjaman pokok yang diberikan kepada seseorang itu memebihi jumlah uang yang dipinjamkan tersebut alias riba 
(bunga). Sebagaimana dalam Al- bersangkutan memerlukannya. Dalam

Qur'an surah Al-Baqarah ayat 278:

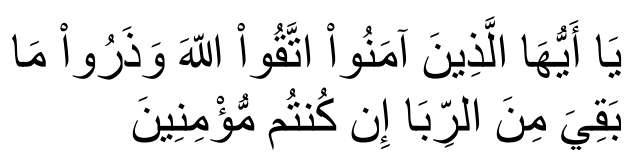

"Hai orang-orang yang beriman, bertakwalah kepada Allah dan tinggalkan sisa riba (yang belum dipungut) jika kamu orang-orang yang beriman". (Q.S. Al-Baqarah: 278)

Ayat diatas menjelaskan bahwa Allah swt. Jelas-jelas melarang adanya praktik riba dalam bertransaksi terutama dalam sebuah lembaga keuangan. Baik bank maupun nonbank yang menyalurkan kredit kepada nasabahnya dan mengharapkan imbalan, balas jasa, bunga (riba) didalamnya. Karena transaksi tersebut dapat diartikan dengan transaksi dalam ekonomi kapitaslis.

\section{METODE PENELITIAN}

Dalam penelitian ini, peneliti menggunakan jenis pendekatan penelitian deskriptif kuantitatif, yaitu peneliti yang menjelaskan pengaruh antara variable-variabel pengujian hipotesis.

Data primer adalah data yang diperoleh atau dikumpulkan oleh orang yang melakukan penelitian atau yang penelitian kali ini menggunakan data primer atau emperis yang di peroleh dari penyebaran angket. Dalam penelitian ini juga angket yang tersebar terdiri dari angket tertutup dan angket terbuka. Angket tertutup dimana masyarakat telah disediakan pilihan pertanyaan yang berkenaan dengan keputusan Pengadilan Agama terhadap Warisan dan jawaban yang di design dengan mengunakan skala liker Responden diminta untuk menjawab pertanyaan-pertanyaan atau pernyataan-pernyataan dengan lima alternatif jawaban yang telah di sediakan oleh peneliti. Responden diminta untuk memilih salah satu jawaban dengan cara memberi tanda atau simbol $(\sqrt{ })$. Angket terbuka di sini dimaksudkan peneliti sebagai alternatif bagi responden jika dimungkinkan jika terdapat faktor lain yang belum tercoferdalam pilihan yang disajikan oleh peneliti.

Data sekunder merupakan data yang diperoleh atau dikumpulkan dari sumber yang telah ada. Data itu biasanya diperoleh dari perpustakaan atau dari laporan-laporan peneliti yang terdahulu. 
Populasi adalah wilayah generalisasi yang terdiri atas objek/subjek yang mempunyai kualitas dan karakteristik tertentu yang di tetapkan oleh peneliti untuk di pelajari dan kemudian ditarik kesimpulannya.

Populasi dalam penelitian ini adalah seluruh masyarakat indonesia yang tinggal di kota makassar. Karena jumlah data yang sangat banyak maka dalam melakukan penelitian ini penulis menggunakan metode sampel.

Sampel adalah sebagian dari jumlah dan karakteristik yang dimiliki oleh populasi tersebut, maka dari itu sampel dari penelitian ini adalah narasumber yang berada di dalam lokasi penelitian peneliti dengan jumlah sampel sebanyak 200 0rang.

Teknik yang di pergunakan dalam proses pengumpulan data dalam penelitianini terdiri atas metode angket atau koesioner, dokumentasi, obserpasi dan metode wawancara untuk melengkapi data yang diperoleh melalui angket.

Analisis data dilakukan dengan cara analisis kuantitatif dengan menggunakan metode Partial Least Square (PLS)-PM dan uji hipotesis.

\section{HASIL PENELITIAN}

Model analisis yang dipergunakan dalam penelitian ini adalah analisis yang diperoleh dari analisis peningkatan ekonomi syariah sebagai pilihan sistem ekonomi alternatif masyarakat dan diolah dengan menggunakan Smart PLS 2. M3. Maka dari hasil pengolahan menggunkan Smart PLS 2 setiap variable yang diteliti dideskripsikan sebagai berikut:

Tabel 1

Variabel Nasabah

\begin{tabular}{llccccc}
\hline \multirow{2}{*}{ No } & \multirow{2}{*}{ Indikator } & \multicolumn{5}{c}{ Penyataan Responden } \\
\cline { 3 - 7 } & & 5 & 4 & 3 & 2 & 1 \\
\hline 1 & $\begin{array}{l}\mathrm{X}_{1} \text { (pengguna layanan jasa } \\
\text { keuangan) }\end{array}$ & 16 & 43 & 1 & - & - \\
\hline 2 & $\mathrm{X}_{2}$ (persepsi gadai) & 12 & 43 & 5 & - & - \\
\hline 3 & $\mathrm{X}_{3}$ (nasabah penyimpan) & 15 & 41 & 4 & - & - \\
\hline 4 & $\mathrm{X}_{4}$ (pemilik dana) & 16 & 39 & 5 & - & - \\
\hline
\end{tabular}

74 | Studi Komparasi Operasional Produk Pegadaian Syariah Dan Gadai Konvensional 
Kesimpulan:

$\mathrm{X}_{1}=$ untuk indikator $\mathrm{X}_{1}$ (pengguna layanan jasa keuangan) yang memilih kategori setujuh : 43. Indikator ini mampu memengaruhi variabel Nasabah.

$\mathrm{X}_{2}=$ untuk indikator $\mathrm{X}_{2}$ (persepsi gadai) yang memiliki kategori setujuh : 43. Indikator ini mampu memengaruhi variabel Nasabah.
$\mathrm{X}_{3}=$ untuk indikator $\mathrm{X}_{3}$ (Nasabah penyimpan) yang memiliki kategori setujuh : 41. Indikator ini mampu memengaruhi variabel Nasabah $\mathrm{X}_{4}=$ untuk indikator $\mathrm{X}_{3}$ (pemilik dana) yang memiliki kategori setujuh : 39. Indikator ini mampu memengaruhi variabel Nasabah.

Tabel 2

Variabel Produk Ar-Rahn

\begin{tabular}{lllllll}
\hline \multirow{2}{*}{ No } & \multirow{2}{*}{ Indikator } & \multicolumn{5}{c}{ Pernyataan Responden } \\
\cline { 3 - 6 } & & 5 & 4 & 3 & 2 & 1 \\
\hline 1 & $\mathrm{X}_{5}$ (jasa simpan) & 10 & 43 & 7 & - & - \\
\hline 2 & $\mathrm{X}_{6}$ (barang jaminan) & 6 & 43 & 11 & - & - \\
\hline 3 & $\mathrm{X}_{7}$ (Akad) & 11 & 44 & 5 & - & - \\
\hline 4 & $\mathrm{X}_{8}$ (prinsip tolong-menolong) & 14 & 40 & 6 & - & -
\end{tabular}

\section{Kesimpulan:}

$\mathrm{X}_{5}=$ Untuk Indikator $\mathrm{X}_{5}$ (jasa simpan) yang memiliki kategori setujuh sebanyak : 43. Indikator ini mampu memengaruhi variabel produk Ar-Rahn.

$\mathrm{X}_{6}=$ Untuk Indikator $\mathrm{X}_{6}$ (barang jaminan) yang memiliki kategori setujuh sebanyak : 43. Indikator ini mampu memengaruhi Variabel produk Ar-Rahn.
$\mathrm{X}_{7}=$ Untuk Indikator $\mathrm{X}_{7}(\mathrm{akad})$ yang memiliki kategori setujuh sebanyak : 44. Indikator ini mampu memengaruhi variabel Produk Ar-Rahn.

$\mathrm{X}_{8}=$ Untuk Indikator $\mathrm{X}_{8}$ (prinsip tolong-menolong) yang memiliki kategori setujuh sebanyak : 40. Indikator ini mampu memengaruhi variabel produk Ar-Rahn. 
Tabel 3

Gadai konvensional

\begin{tabular}{clccccc}
\hline \multirow{2}{*}{ No } & \multirow{2}{*}{ Indikator } & \multicolumn{5}{c}{ Pernyataan Responden } \\
\cline { 3 - 7 } & & 5 & 4 & 3 & 2 & 1 \\
\hline 1 & $\mathrm{X}_{9}$ Bunga (riba) & 8 & 45 & 7 & - & - \\
\hline 2 & $\mathrm{X}_{10}$ (kontrak) & 8 & 48 & 4 & - & - \\
\hline 3 & $\mathrm{X}_{11}$ (jaminan barang & 8 & 52 & 7 & 1 & - \\
& bergerak) & & & & & \\
\hline 4 & $\mathrm{X}_{12}$ (bentuk bisnis) & 10 & 42 & 8 & - & - \\
\hline
\end{tabular}

Kesimpulan:

$\mathrm{X}_{8}=$ untuk Indikator bunga (riba) yang memiliki kategori setujuh sebanyak 45. Indikator ini mampu memengaruhi variabel gadai konvensional.

$\mathrm{X}_{9}=$ untuk Indikator (kontrak) yang memiliki kategori setujuh sebanyak 48. Indikator ini mampu memengaruhi variabel gadai konvensional.
$\mathrm{X}_{10}=$ untuk Indikator (jaminan barang bergerak) yang memiliki kategori setujuh sebanyak 52. Indikator ini mampu memengaruhi variabel gadai konvensional.

$\mathrm{X}_{11}=$ untuk Indikator (bentuk bisnis) yang memiliki kategori sangat setujuh sebanyak 42. Indikator ini mampu mempengaruhi variabel gadai konvensional

Tabel 4

Variabel Keputusan nasabah

\begin{tabular}{lllllll}
\hline \multirow{2}{*}{ No } & \multirow{2}{*}{ Indikator } & \multicolumn{6}{c}{ Pernyataan Responden } \\
\cline { 3 - 7 } & & 5 & 4 & 3 & 2 & 1 \\
\hline 1 & $\mathrm{Y}_{1}$ (kebersihan) & 9 & 44 & 6 & 1 & - \\
\hline 2 & $\mathrm{Y}_{2}$ (pelayanan) & 13 & 47 & - & - & - \\
\hline 3 & $\mathrm{Y}_{3}$ (keuntungan) & 8 & 44 & 8 & - & - \\
\hline 4 & $\mathrm{Y}_{4}$ (kualitas produk) & 10 & 46 & 4 & - & - \\
\hline
\end{tabular}

Kesimpulan: $\mathrm{Y}_{1}=$ untuk Indikator (kebersihan) yang memiliki kategori setujuh 
sebanyak 44. Indikator ini mampu memengaruhi variabel keputusan nasabah.

$\mathrm{Y}_{2}=$ untuk Indikator (pelayanan) yang memiliki kategori setujuh sebanyak 47. Indikator ini mampu memengaruhi variabel gadai konvensional.

$\mathrm{Y}_{3}=$ untuk Indikator (keuntungan) yang memiliki kategori setujuh sebanyak 44. Indikator ini mampu memengaruhi variabel keputusan nasabah.

$\mathrm{Y}_{4}=$ untuk Indikator (kualitas produk) yang memiliki kategori sangat setujuh sebanyak 46. Indikator ini mampu mempengaruhi variabel keputusan nasabah.

\section{Uji Validitas dan Reliability}

Metode yang digunakan dalam penelitian ini adalah model Smart + $P L S$ 2.0. pengaruh nasabah terhaadap produk gadai dengan keputusan nasabah yang dimana setiap konstrak diukur oleh tiga indikator yang bersifat reflelitif.

\section{Evaluasi Model Pengukuran}

Evaluasi pengukuran adalah evaluasi hubungan antara konstrak dan indikatornya. Indikator ini meliputi 2 tahap convergent validity distriminant validity. Convergent validity dapat dievaluasi dalam 3 tahap. Yaitu:

1. Indikator validity

2. Redibility konstrak

3. Nilai avegare vanue extracted $(A V E)$

Syarat jika faktor loading > 0,5 dan nilai + stal $<2,0$ maka maka dikeluarkan dari model. Dan untuk model penelitian tersebut yang dimana:

1. Variabel nasabah $(\xi)$ yang dimana

$\mathrm{X}_{1}(1,075)>0,5$

$\mathrm{X}_{2}(11,528)>0,5$

$\mathrm{X}_{3}(5,525)>0,5$

$\mathrm{X}_{4}(12,641)>0,5$

Artinya nilai faktor loading $>0,5$.

Ini menunjukkan bahwa data ini benar-benar sangat akurat (valid).

2. Variabel produk Ar-Rahn $(\propto)$ yang dimana $\mathrm{X}_{5}(13,072)>0,5$.

$\mathrm{X}_{6}(5,69)>0,5$

$\mathrm{X}_{7}(7,107)>0,5$

$\mathrm{X}_{8}(6,151)>0,5$

Olah data tersebut menunjukkan faktor loading $>0,5$ yang artinya data menunjukkan sangat akurat (valid).

3. Varibel gadai konvensional $(\beta)$ yang dimana $X_{9}(5,081)>0,5$ $\mathrm{X}_{10}(3,007)>0,5$ 
$X_{11}(15,254)>0,5$

$\mathrm{X}_{12}(7,134)>0,5$

Olah data tersebut menunjukkan faktor loading >0,5 yang diartikan data sangat akurat (valid).

4. Variabel keputusan nasabah $(\gamma) \mathrm{Y}_{1}$ $(0,599)>0,5$

$\mathrm{Y}_{2}(1,176)>0,5$
$\mathrm{Y}_{3}(0,116)<0,5$

(Keluar dari model).

$\mathrm{Y}_{4}(1,324)>0,5$

Data diatas menunjukkan bahwa Y1, Y2, dan Y4 terbukti sangat akurat (valid). Untuk variabel nasabah 5,080 $>2$ cukup redible terhadap gadai konvensional. Untuk variabel gadai konvensional terhadap variabel keputusan nasabah. Untuk variabel

Dari data yang diperoleh nilai Composite Rediability atau Corombacth Alpha lebih dari 0,7 yang dimana variable gadai konvensional dengan nilai composite rediability kurang redible untuk penilai composite readability dan crombacth alpha dapat dikatakan redible.

Penyajian variabel keputusan nasabah dengan nilai composite rediability $0,07<0,7$ yang berarti tidak redible. Untuk crombatch alpha $0,07<$ 0,418 yang berarti nilainya dikatakan produk Ar-Rahn terhadap gadai konvensional 6,793>2 (redible). Untuk variabel nasabah terhadap produk Ar-Rahn 12,03> 2 (redible). Untuk variabel gadai konvensional nilai statis $1,26<2$ (tidak redible). Untuk variabel nasabah terhadap keputusan nasabah $0,64<$ (tidak redible). Semua + statis $<2$ dikeluarkan dari model.

Penyajian selanjutnya dari Convergent Validilty adalah redibilities dengan melihat Output Composite Redibility atau Crombacth Alpha: berikut materi yang dikatakan redible yang dimana nilai Composite Redibility $>0,70$.

tidak redible. Penyajian untuk variabel nasabah 0,78>0,7 yang berarti redible dan crombatch alpha 60,07>0,68 yang berarti redible. Penyajian variabel produk Ar-Rahn yang dimana Composite Relidity 0,76>0,7 yang berarti redible. Nilai Crombatch Alpha $0,609>0,5$. Penulisan nilai AVE untuk keempat variable lebih kecil dari 0,5

\section{KESIMPULAN}

Dari seluruh hasil olah data penelitian dan telah di analisa secara rinci dapat disimpulkan bahwa: 1) 
Variabel gadai konvensional memiliki korelasi signifikan terhadap variabel nasabah yan dimana korelasi 1,117 > 0,7. 2) Variabel gadai konvensional memiliki korelasi terhadap variabel keputusan nasabah sebsar $0,655<0,7$ tidak berkolerasi signifikan. 3) positif yang dimana nilainya sebesar 1,851 > 0,7. 4) Variabel produk ArRahn 4,951>0,7 berpengaruh positif signifikan terhadap variabel nasabah. 5) Variabel produk Ar-Rahn berkolerasi $1,017>0,7$ memiliki kolerasi positif signifikan.

Variabel nasabah berkolerasi signifikan

\section{DAFTAR PUSTAKA}

Abdul Manan,. Hukum Ekonomi Syariah. Dalam perspektif kewenangan peradilan agama. (Kencana Prenadamedia Group). 2012

Adimarwan Karim, Bank Islam (analisis fiqih dan keuangan), Jakarta: PT. Raja Grafindo Persada, 2004

Andri Soemitra, M.A., Bank \& Lembaga Keuangan Syariah, (Jakarta: Kencana/Prenadamedia Group, 2009)

Apridar. Ekonomi Internasional. Sejarah, teori, konsep, dan permasalahan dalam aplikasinya. (Yogakarta/Graha Ilmu) 2012.

H. Muslich Anshori dan Hj. Sri Iswati. Buku ajar metodologi penelitian kuantitatif (Surabaya) Pusat Penelitian dan percetakan UNAIR (AUP) 2009

Hasan, Iqbal. 2003. Pokok-pokok materi statistik 1(statistik deskripif). Jakarta: PT Bumi Aksara.

Hasan, M Ali. 2003, Berbagai macam transaksi dalam islam ( fiqh muamalah), Jakarta : PT. Raja Grafindo Persada.

Hasan, M Ali. 2003, Berbagai macam transaksi dalam islam ( fiqh muamalah), Jakarta : PT. Raja Grafindo Persada.

Hasan, M Ali. 2003. Fiqh Muamalat, Cet 1: Jakarta : PT Raja Grafindo Persada.

Herman O.A Word.Partial Least Square (PLS)

Julius R. Latumaerissa, Bank \& Lembaga Keuangan Lain, (Jakarta Selatan/Salemba Empat) 2013

Mardani. 2011. Ayat-Ayat dan Hadist Ekonomi Syariah ( Jakarta : rajawali pers).

Sugiono, Metode Penelitian Kuantitatif (Alfabeta, Bandung) 2014.

Thamrin Abdullah, Francis Tantri,. Manajemen Pemasaran. (PT. Raja Grafindo Persada) 2014

Tim Penyusun, Pedoman penulisan karya tulis ilmiah (proposal, skripsi, makalah, dan laporan penelitian) Universitas Muhammadiyah Makassar, 2015

Wilson Bangun, Teori Ekonomi Mikro (PT. Refika Aditama) 2010

Wilson Bangun, Teori Ekonomi Mikro, cet. 1 dan 2, PT Refika Aditama Bandung, 2007. 